\title{
PERSEPSI GURU TERHADAP GAYA KEPEMIMPINAN KEPALA SD NEGERI 11 KAPEH PANJI KECAMATAN BANUHAMPU KABUPATEN AGAM
}

Fakhri Syafrizal

Pegawai Tata Usaha SD Negeri 11 Kapeh Panji Kecamatan Banuhampu, Kabupaten Agam e-mail: fakhripanji234@gmail.com

\begin{abstract}
This qualitative case study was aimed at disclosing the teachers' perception on headmaster's leadership style of Primary School 11 Kapeh Panji. The interview and observation were used as instruments to collect the data. The results revealed that the headmaster of Primary School 11 Kapeh Panji was democratic, humorous and communicative. The headmaster was also as motivator in this school.
\end{abstract}

Keywords: Teachers' Perception, Leadership Style, Headmaster, Primary School 11 Kapeh Panji

\section{PENDAHULUAN}

Pemimpin adalah motor penggerak sebuah lembaga atau organisasi. Keberadaan seorang pemimpin akan menentukan arah dan tujuan dari sebuah lembaga tersebut. Dalam memimpin sebuah organisasi, seorang pemimpin harus memiliki jiwa kepemimpinan. Munawaroh (2011) menyatakan bahwa keberadaan pemimpin memegang peranan penting dalam suatu organisasi. Peran seorang pemimpin adalah sebagai penunjuk arah dan tujuan di masa depan (direct setter), agen perubahan (change agent), negosiator (spokes person), dan sebagai pembina (coach). Permadi dan Arifin (2011) mengutip pendapat Lipham (1985) menyatakan bahwa "leadership is that behavior of an individual that initiates a new structure in interaction within aiocial system by changing the goals, objective, configuration, procedures, inputs, processes, or outputs of the system". Lebih lanjut Siagian (1982) mendefenisikan kepemimpinan sebagai keterampilan dan kemampuan seseorang mempengaruhi perilaku orang lain, baik yang kedudukannya lebih tinggi setingkat maupun yang lebih rendah dari padanya, dalam berpikir dan bertindak agar perilaku yang semula mungkin individualistik dan edgosentrik berubah menjadi perilaku organisasional. Pengertian di atas menunujukkan bahwa faktor kepemimpinan menjadi faktor utama dalam upaya mencapai tujuan organisasi. 
Dalam ranah pendidikan, keberadaan pemimpin sekolah atau yang lebih dikenal dengan kepala sekolah (headmaster) seperti halnya pimpinan lainnya, juga memegang peranan penting terhadap keberhasilan proses pendidikan di sekolah yang dipimpinnya. Bahkan pendidikan yang merupakan pilar utama dalam membangun bangsa harus berupaya menghasilkan output yang berkualitas sebagai generasi penerus bangsa. Hal ini tentu sangat erat kaitannya dengan peran kepala sekolah sebagai pemimpin tertinggi sebuah lembaga pendidikan. Kepala sekolah merupakan aktor utama penentu keberhasilan lembaga pendidikan yang dipimpinya. Sosok kepala sekolah akan menjadi penentu keberhasilan dalam mencapai tujuan tersebut. Mulyasa (2009) menyatakan bahwa kepala sekolah merupakan salah satu komponen pendidikan yang paling berperan dalam meningkatkan kualitas pendidikan. Rohiat (2010) menyatakan bahwa Kepala Sekolah sebagai manajer menempati posisi yang telah ditentukan di dalam organisasi sekolah. Kepala sekolah mempunyai posisi puncak yang memegang kunci keberhasilan dalam mencapai tujuan yang telah ditentukan. Kondisi tersebut menunjukkan bahwa kepala sekolah sebagai pemegang jasa suatu bidang professional yang sangat khusus. Rohiat (2010) Sallis
(1993) berpendapat bahwa kepemimpinan pendidikan membutuhkan perspektif sebagai berikut 1) visi dan symbol, guru kepala atau kepala sekolah harus mengomunikasikan nilai-nilai institusi kepada staffnya, siswa dan masyarakat luas; 2) management by walking about yang merupakan gaya kepemimpinan bagi setiap institusi; 3) for the kids (untuk anak-anak), istilah dalam pendidikan yang berarti ekuivalen dengan dekat pada pandangan; 4) autonomi, pengalaman, dan dukungan terhadap kegagalan, pemimpin pendidikan harus mendorong inovasi di antara stafnya dan siap terhadap kegagalan yang pasti muncul dalam melakukan inovasi; 5) menciptakan rasa "kekeluargaan ", pemimpin perlu menciptakan suatu persaan sebagai komunitas di antara siswa, murid, orang tua, guru dan staff pendukung; dan 6) rasa sebagai keseluruhan, ritme, keinginan kuat, intensitas, dan antusiasme.

Supriadi (2009) menyatakan bahwa kepala sekolah merupakan jabatan administratif. Dalam jabatan tersebutlah prinsip-prinsip kepemimpinan dioperasionalisasikan. Dengan kata lain, seorang kepala sekolah haruslah individu yang memiliki unsurunsur kepemimpinan yang memadai, karena dengan kepemimpinannya itu, kepala sekolah menahkodai perjalanan sebuah kapal yang bernama sekolah mencapai pantai tujuan yakni tujuan pembelajaran itu 
sendiri. Artinya kepala sekolah adalah aktor utama yang memegang peranan penting dalam mencapai tujuan pendidikan tersebut.

Di samping itu, hal yang tak kalah penting dilakukan oleh kepala sekolah dalam memimpin sekolah adalah komunikasi dan interkasi dengan orang-orang yang terlibat dalam dunia pendidikan tersebut, baik yang terlibat secara langsung maupun tidak langsung. Interaksi dan komunikasi terhadap mereka yang terlibat langsung dalam dunia pendidikan ini dapat dilihat dari interaksi yang dilakukan oleh kepala sekolah dengan para guru dan pegawai sekolah. Interaksi dan komunikasi yang dilakukan oleh kepala sekolah merupakan salah satu bentuk dari pendekatan perilaku.

Purwanto (2010) mengemukakan bahwa pendekatan perilaku (behavioral approach) merupakan pendekatan yang berdasarkan pemikiran bahwa keberhasilan atau kegagalan pemimpin ditentukan oleh sikap dan gaya kepemimpinan yang dilakukan oleh pemimpin yang bersangkutan. Sikap dan gaya kepemimpinan itu tampak dalam kegiatannya sehari-hari, dalam hal bagaimana cara memimpin, memberi perintah, membagi tugas dan wewenangnya, cara berkomunikasi, cara mendorong semangat kerja bawahan, cara memberi bimbingan dan pengawasan, cara membina disiplin kerja bawahan, cara menyelenggarakan dan memimpin rapat anggota, cara mengambil keputusan dan sebagainya. Pada akhirnya, semua bentuk perilaku inilah yang nantinya akan melahirkan berbagai pendapat tentang gaya kepemimpinan seorang pimpinan. Sikap dan gaya kepemimpinan seseorang merupakan jati diri dan karakter yang ada pada pribadi pemimpin tersebut. Setiap sikap dan gaya kepemimpinan yang lahir dari sesorang pemimpin, pada akhirnya akan bermuara pada sebuah persepsi dan penilaian dari bawahannya, tak terkecuali pada sosok kepala sekolah. Penilaian dan persepsi yang lahir dari para bawahan ini akan memberikan pengaruh terhadap kinerja bawahan itu sendiri, yang nantinya juga akan berdampak pada kinerja organisasi.

Sebagai seorang pemimpin lembaga pendidikan, sikap dan gaya kepemimpinan kepala sekolah juga bermuara pada persepsi dan penilaian oleh para guru. Persepsi dan penilaian yang diberikan oleh para guru ada yang bersifat positif, namun tak jarang yang bersifat negatif. Jika penilaian dan persepsi yang diberikan bersifat positif, hal ini mengindikasikan bahwa kepala sekolah dengan sikap dan gaya kepemimpinannya telah mampu menjalankan tugas dan fungsinya dengan baik. Namun bagaimana jika sikap dan gaya kepemimpinan kepala sekolah bermuara pada penilaian dan pandangan yang negatif dari para guru dan 
pegawai. Tentu hal ini akan menjadi sebuah permasalahan yang perlu diwaspadai.

Dalam menjalankan tugas dan fungsinya, sikap dan kepemimpinan seorang kepala sekolah tak jarang mendapat penilaian dan persepsi yang negatif dari para guru. Penilaian dan persepsi yang negatif ini akan berdampak pada tidak harmonisnya hubungan antara kepala sekolah dan guru. Hubungan yang tidak harmonis antara kepala sekolah dan guru ini juga akan berdampak terhadap iklim kerja dan kinerja guru, serta akan memberikan dampak pada kinerja lembaga pendidikan. Hubungan yang tidak harmonis ini merupakan sebuah bom waktu yang nantinya akan menghancurkan visi, misi dan tujuan pendidikan yang telah ditetapkan. Bagaimana mungkin visi, misi dan tujuan lembaga bisa tercapai, kalau orang-orang yang terlibat di dalamnya satu sama lainnya tidak harmonis. Seorang kepala sekolah yang seharusnya dihormati dan menjadi panutan bagi para guru, ternyata menjadi buah bibir dan sering menjadi topik pembicaraan antara para guru. Segala bentuk penilaian negatif lahir dari guru terhadap sikap dan gaya kepemimpinan kepala sekolah.

Daryanto (2008) menyatakan bahwa kepala sekolah merupakan personel yang bertanggung jawab terhadap seluruh kegiatan sekolah. Ia mempunyai wewenang dan tanggung jawab penuh untuk menyelenggarakan seluruh kegiatan pendidikan dalam lingkungan sekolah yang dipimpinnya. Kepala sekolah tidak hanya bertanggung jawab atas kelancaran jalannya sekolah secara teknis akademis saja, akan tetapi segala kegiatan, keadaan lingkungan sekolah, kondisi dan situasinya serta hubungan dengan masyarakat sekitarnya merupakan tanggung jawabnya pula. Inisiatif dan kreatif yang mengarah kepada perkembangan dan kemajuan sekolah adalah merupakan tugas dan tanggung jawab kepala sekolah. Namun demikian, dalam usaha memajukan sekolah dan menanggulangi kesulitan yang dialami sekolah baik yang berupa atau bersifat material seperti perbaikan gedung, penambahan ruang, penambahan perlengkapan dan sebagainya maupun yang bersangkutan dengan pendidikan anakanak, kepala sekolah tidak dapat bekerja sendiri. Kepala sekolah harus bekerjasama dengan para guru yang dipimpinnya.

Tatkala kepala sekolah yang telah dinilai oleh para guru sebagai pemimpin yang otorier, angkuh, dan hanya mementingkan pandapat pribadi ini dalam membangun kerja sama dengan para guru, tentu kerja sama yang baik tersebut sulit untuk didapatkan. Interaksi dan komunikasi tidak akan berjalan dengan baik bila telah ada penilian yang negatif itu lahir di kalangan para pendidik 
tersebut. Hal ini nantinya akan bermuara pada kinerja lembaga pendidikan tersebut. Sekolah atau lembaga pendidikan tersebut ini nantinya akan sulit untuk mewujudkan visi, misi dan tujuan pendidikan yang telah ditetapkan, dan secara otomatis akan berdampak pada rendahnya mutu dan kualitas pendidikan tersebut. Jika hal ini terjadi pada semua lembaga pendidikan di Indonesia, tentu tujuan pendidikan yang telah ditetapkan akan sangat sulit dicapai, dan pada akhirnya berdampak pada rendahnya mutu dan kualitas sumber daya manusia Indonesia. Ketika mutu dan kualitas sumber daya manusia suatu negara rendah, maka negara tersebut akan mengalami kemunduran dan bahkan kehancuran, sebab pendidikan merupakan pilar utama maju atau mudurnya peradaban sebuah bangsa dan negara.

Latar belakang yang peneliti uraikan di atas penting untuk dikaji. Penelitian ini peneliti fokuskan pada SD Negeri 11 Kapeh Panji Kecamatan Banuhampu Kabupaten Agam. Hal ini didasari karena SD merupakan sebuah lembaga pendidikan dasar yang harus menjadi perhatian penuh, sebab jika diibaratkan pada sebuah bangunan, pondasi dan dasar sebuah bengunan merupakan hal yang paling vital. Jika pondasi dan dasar bangunan kuat, maka bangunan tersebut akan berdiri dengan kokoh, namun sebaliknya, jika pondasi dan dasarnya tidak kokoh, maka bangunan yang berdiri di atasnya akan hancur. Dalam penelitian ini, peneliti menggali informasi tentang persepsi para guru di SD Negeri 11 Kapeh Panji ini terhadap gaya kepemimpinan kepala sekolahnya.

\section{METODE PENELITIAN}

Penelitian ini merupakan penelitian kualitatif, di mana pada penelitian ini peneliti mengidentifikasi data dari para informan. Susilo (2010) dan Sutopo dan Arief (2010) menyatakan bahwa penelitian kualitatif merupakan penelitian yang ditujukan untuk melakukan deskripsi dan analisis terhadap fenomena, peristiwa, aktivitas sosial, sikap, persepsi dari setiap individu maupun pada kelompok tertentu. Penelitian jenis ini bersifat induktif, di mana data di lokasi riset akan menjadi sumber utama adanya fenomena dan permasalahan dalam proses pengamatan yang dilakukan. Selanjutnya Sarwono (2006) dan Marshal (1995) menyatakan bahwa kualitatif riset didefinisikan sebagai suatu proses yang mencoba untuk mendapatkan pemahaman yang lebih baik mengenai kompleksitas yang ada dalam interaksi manusia. Dari defenisi di atas menunjukkan kata kunci dalam riset kualitatif yaitu proses, pemahamnan, kompleksitas, interaksi, dan manusia. 
Sarwono (2006) menyatakan bahwa desain penelitian kualitatif bersifat fleksibel dan berubah-ubah sesuai dengan kondisi lapangan tidak seperti desain riset penelitian kuantitatif yang bersifat tetap, baku dan tidak berubah-ubah. Oleh karena itu peranan peneliti sangat dominan dalam menentukan keberhasilan penelitian yang dilaksanakan.

Uraian di atas memberikan gambaran bahwa penelitian kualitataif merupakan sebuah penelitian yang berupaya menggali dan menganalisa pemasalahan dan peristiawa yang terjadi dalam sebuah kelompok dan individu. Penelitian ini mengajak peneliti untuk terjun langsung ke lapangan dalam upaya memperoleh data dan informasi yang nantinya akan djiadikan bahan kajian dan pembuatan laporan. Artinya, keberhasilan penelitian ini sangat ditentukan sekali oleh kesungguhan usaha dan upaya peneliti dalam mengumpulkan data dan informasi.

Dalam melakukan identifikasi dan pengumpulan data, peneliti melakukan wawancara langsung dengan beberapa orang guru. Wawancara yang peneliti lakukan adalah wawancara tidak tersturktur, serta melakukan pengamatan (observasi) langsung. Djamaan dan Aan (2011) mengungkapkan bahwa wawancara merupakan teknik pengumpulan data yang sering digunakan dalam penelitian kualitatif. Melaksanakan teknik wawancara berarti melakukan interaksi komunikasi atau percakapan antara pewawancara (interviewer) dan terwawancara (interviewee) dengan maksud menghimpun informasi dari interviewee. Interviewee pada penelitian kualitatif adalah informan yang daripadanya pengetahuan dan pemahaman diperoleh. Menurut Kothari (2004) "The interview method of collecting data involves presentation of oral-verbal stimuli and reply in terms of oral-verbal responses. This method cam be use though personal interviews and, if possible though telephone interviews". Dengan arti kata bahwa wawancara merupakan sebuah metode pengumpulan data di mana peneliti melakukan komunikasi dan interaksi dengan orang-orang yang menjadi sumber informasi.

Di samping wawancara, data dalam penelitian ini diperoleh melalui observasi langsung di lapangan. Sarwono (2006) menyatakan bahwa kegiatan observasi meliputi melakukan pencatatan secara sistematik kejadian-kejadian, perilaku, obyek-obyek yang dilihat dan hal- hal lain yang diperlukan dalam mendukung penelitian yang sedang dilakukan. Kothari (2004) mengungkapkan bahwa the observation method is the most commonly used method specially in studies relating to behavioural sciences. In a way we all observe things around us, but this sort of observation is not scientific observation. Observation 
becomes a scientific tool and the method of data collection for the researcher, when it serves a formulated research purpose, is systematically planned and recorded and is subjected to checks and controls on validity and reliability. Under the observation method, the information is sought by way of investigator's own direct observation without asking from the respondent.

\section{HASIL PENELITIAN DAN PEMBAHASAN}

\section{Interaksi dan Komunikasi Kepala Sekolah}

SD Negeri 11 Kapeh Panji dipimpin oleh seorang kepala sekolah yang bernama Drs. Aditiawarman. Drs. Aditiawarman diangkat menjadi kepala sekolah sejak tanggal 1 Mei 2013. Ini artinya bahwa Drs. Aditiawarman telah menjabat sebagai kepala sekolah lebih kurang 2 tahun.

Dari hasil wawancara yang peneliti lakukan dengan beberapa orang guru (30 November sampai 3 Desember 2015), di mana dalam melaksanakan tugasnya "kepala sekolah melakukan interaksi dan komunikasi dengan para guru". Dalam menjalankan tugas dan fungsinya, interaksi dan komunikasi yang dilakukan oleh kepala sekolah selaku pimpinan di sekolah itu akan memberikan dampak yang sangat besar terhadap sekolah tersebut. Hal ini merupakan sesuatu yang sangat penting dalam sebuah organisasi. Interaksi dan komunikasi sangat berperan besar dalam mencapai tujuan organisasi. Bahkan bisa dikatakan tidak akan ada organisasi atau lembaga tanpa interksi dan komunikasi para personilnya. Hal ini senada dengan pengamatan yang peneliti lakukan bahwa dalam menajalankan tugas dan fungsinya sebagai kepala sekolah, Drs. Aditiawarman selalu melakukan interaksi dan komunikasi dengan para personilnya.

Di samping itu, melalui pengamatan peneliti, diperoleh data bentuk interaksi dan komunikasi yang dilakukan oleh kepala sekolah dengan guru di antaranya berupa kepala sekolah selalu memberikan saran terhadap persoalan yang dihadapi oleh guru dalam upaya menyelesaikan persoalan di sekolah dan bahkan tak jarang juga guru meminta saran kepada kepala sekolah mengenai permasalahan dalam keluarga. Dalam menciptakan iklim yang kodusif serta kerja sama tim yang baik, tentu dalam organisasi tersebut harus terjalin hubungan yang baik, persepsi yang baik serta sikap yang baik pula. Hubungan yang baik dan persepsi yang baik antara bawahan dan atasan merupakan kunci terciptanya iklim yang kondusif dan awal terbentuknya kerja sama tim yang baik. Hubungan yang baik tersebut berawal dari komunikasi dan interaksi yang terjalin dengan baik. Semua 
itu nantinya akan memberikan dampak terhadap kinerja sekolah tersebut.

Berdasarkan hasil wawancara dengan beberapa orang guru (30 November sampai 3 Desember 2015) diperoleh data bahwa "interaksi yang dilakukan dapat berupa bimbingan, tanya jawab, teguran dan kegiatan rapat, interaksi di bidang proses pembelajaran, interaksi bidang administrasi, pembinaan dan bimbingan pada siswa, interaksi dalam bidang kedisiplinan, pembinaan kelas, interaksi untuk menjadikan sekolah sebagai lingkungan yang sehat, interaksi dalam menjalin kerja sama dengan teman sejawat, bimbingan dalam pembelajaran, bimbingan dalam bentuk kedisiplinan”. Senada dengan itu, dari hasil pengamatan peneliti di mana para pegawai dan guru sering meminta masukan dan saran kepada kepala sekolah dalam upaya menyelesaikan masalah yang terjadi di sekolah. Pada uraian ini menggambarkan bahwa kepala sekolah selaku pucuk pimpinan telah menjalankan tugas dan fungsinya yakni memberikan bimbingan, arahan dan pembinaan pada para guru.

Selain berinteraksi dengan guru, kepala sekolah juga melakukan komunikasi dan interaksi dengan siswa. Bentuk interaksi yang dilakukan dengan siswa berupa bimbingan yang dilakukan dengan siswa seperti bimbingan belajar pada siswa, motivasi, penyampaian tata tertib, serta pesan-pesan lain pada saat upacara bendara. Kepala sekolah juga melakukannya dengan anak yang bermasalah. Namun secara umum, interaksi yang dilakukan kepala sekolah dengan siswa sekitar 30-40\%, sebab untuk menyelesaikan masalah siswa lebih diutamakan pada guru kelas masing-masing.

Dari penelitian di atas dapat disimpulkan bahwa kepala sekolah telah mampu melakukan bentuk komunikasi dan interaksi yang baik dengan para guru dan bawahannya, serta para siswa karena dengan adanya interaksi dan komunikasi yang lancar, tugas kepala sekolah dapat dilaksanakan dengan baik, sehingga akan berdampak pada terciptanya hubungan baik antara atasan dan bawahan serta iklim kerja dan kerja sama di sekolah tersebut. Dengan arti kata bahwa komunikasi dan interaksi memberikan dampak yang sangat signifikan sekali terhadap iklim organisasi dan berdampak pada kinerja kepala sekolah, guru dan sekolah itu sendiri.

\section{Motivasi yang Diberikan Kepala Sekolah}

Salah satu fungsi kepala sekolah adalah sebagai motivator. Kepala sekolah sebagai pimpinan barharap agar semua guru mampu bekerja secara maksimal dan optimal. Oleh karena itu, kepala sekolah harus mampu membangkitkan semangat 
kerja dan memotivasi para guru untuk dapat memberikan yang terbaik untuk pendidikan di sekolah. Mulyasa (2009) menyatakan bahwa sebagai motivator, kepala sekolah harus memiliki strategi yang tepat untuk memberikan motivasi kepada para tenaga kependidikan dalam melakukan berbagai tugas dan fungsinya. Motivasi ini dapat ditumbuhkan melalui pengaturan lingkungan fisik, pengaturan suasana kerja, disiplin, dorongan, penghargaan secara efektif, dan penyediaan berbagai sumber balajar melalui pengembangan Pusat Sumber Belajar (PSB).

Dalam hal ini, di SD Negeri 11 Kapeh Panji, melalui wawanacara dengan para guru (30 November sampai 3 Desember 2015), diperoleh data bahwasanya "kepala sekolah dalam menjalankan tugas senantiasa memberikan motivasi kapada para guru untuk bisa mengajar dengan baik dan optimal". Hal ini senada dengan hasil pengamatan peneliti di mana dalam menjalankan tugasnya, kepala sekolah sering memberikan motivasi pada guru dalam menjalankan tugas dan fungsinya. Kepala sekolah selalu mendorong guru untuk meningkatkan kinerjanya. Adapun bentuk motivasi yang diberikan kepala sekolah kepada para guru di antaranya pemberian piagam penghargaan, memberikan pujian terhadap prestasi yang diperoleh. Hal ini mungkin lebih tepat dikatakan dengan reward, namun dapat dijadikan sebagai motivasi demi mencapai prestasi di masa yang akan datang. Mulyasa (2009) menyatakan bahwa penghargaan (reward) ini sangat penting untuk meningkatkan profesionalisme tenaga kependidikan dan untuk mengurangi kegiatan yang kurang produktif. Melalui penghargaan ini tenaga kependidikan dapat diransang untuk meningkatkan profesionalisme kerjanya secara positif dan produktif. Pelaksanaan penghargaan dapat dikaitkan dengan prestasi tenaga kependidikan secara terbuka, sehingga mereka memiliki peluang untuk meraihnya.

Dari hasil wawancara dengan para guru (30 November-3 Desember 2015) diperoleh juga data bahwa "pemberian motivasi yang dilakukan oleh kepala sekoah dengan menggunakan bahasa yang santun, baik, menyenangkan, bjiaksana serta penuh persahabatan dan tidak memunculkan perbedaan antara atasan dan bawahan. Mulyasa (2009) menyatakan bahwa motivasi merupakan bagian yang penting dalam setiap kegiatan, tanpa motivasi tidak ada kegiatan yang nyata. Menurut Morgan, motivasi merupakan tenaga pendorong atau penarik yang menyebabkan adanya tingkah laku kearah suatu tujuan tertentu. Maslow (1970) mengemukakan bahwa motivasi 
adalah tenaga pendorong dari dalam yang menyebabkan manusia berbuat sesuatu atau berusaha untuk memenuhi kebutuhannya.

\section{Bimbingan yang Diberikan Kepala Sekolah}

Di antara peran dan fungsi kepala sekolah yaitu sebagai pembimbing. Kepala sekolah sebagai orang yang dituakan dalam sebuah organisasi haruslah memberikan bimbingan, arahan dan pembinaan kepada para guru dan pegawai agar tujuan yang dicita-citakan dapat tercapai. Keputusan Menteri Pendidikan dan Kebudayaan Nomor 0296/U/1996, merupakan landasan penilaian kinerja kepala sekolah. Kepala sekolah selaku educator harus memiliki kemampuan untuk membimbing guru, membimbing tenaga kependidikan non-guru, membimbing perserta didik, mengembangkan tenaga kependidikan, mengikuti perkembangan IPTEK dan memberikan contoh mengajar.

Melalui wawancara beberapa guru (30 November-3 Desember 2015) di mana peneliti juga memperoleh data bahwa "kepala sekolah ada memberikan bimbingan kepada para guru dan pegawai. Adapun bentuk bimbingan itu di antaranya bimbingan dalam melaksanakan proses pembelajaran, bimbingan dalam melengkapi administrasi guru, bimbingan kerier, dan bimbingan sosial. Khusus pada bimbingan pada proses pembelajaran kepala sekolah tidak langsung memberikan praktek mengajar di depan kelas, tapi bimbingan diberikan melalui kata-kata". Semua bimbingan yang diberikan oleh kepala sekolah tersebut dalam rangka meningkatkan profesionalisme para guru, yang pada akhirnya nanti mampu melahirkan kinerja sekolah yang baik.

Senana dengan itu, dari pengamatan yang peneliti lakukan di dapat data bahwa kepala sekolah memberikan bimbingan pada guru. Adapun bentuk bimbingan tersebut dapat dibagi manjadi (1) bimbingan akademik berupa bimbingan dalam upaya meningkatkan kegiatan belajar mengajar agar lebih baik, (2) bimbingan karier, di mana kepala sekolah memberikan bimbingan pada guru dalam usaha kenaikan pangkat dan golongan dan (3) bimbingan sosial yakni kepala sekolah memberikan bimbingan tentang pergaulan sesama guru, guru dengan siswa, guru dengan orang tua dan masyarakat. Kepala sekolah memberikan bimbingan dan arahan dengan penyampaian yang terbuka, dan juga mempraktikannya.

\section{Gaya Kepala dalam Memimpin Rapat}

Mulyasa (2009) menyatakan bahwa banyaknya masalah yang dihadapi kepala sekolah dalam mengembangkan berbagai inovasi pendidikan di sekolah, menuntut kepala sekolah untuk mampu melakukan 
perundingan dengan tenaga kependidikan. Perundingan tersebut biasanya disebut dengan rapat. Rapat merupakan suatu bentuk pertemuan kelompok yang bersifat tatap muka untuk merencanakan suatu program, memecahkan masalah, dan untuk mendapatkan suatu kesepakatan bersama.

Dalam hal ini, dari data yang peneliti peroleh melalui wawancara dengan para guru (30 November sampai 3 Desember 2015), diketahui bahwa "dalam memimpin rapat dan pertemuan, kepala sekolah bersikap demokratis, terbuka, fleksibel, kekeluargaan, menggunakan bahasa yang santun dan mudah dipahami. Di samping itu kepala sekolah sering meminta pandapat anggota rapat tentang persoalan yang akan diselesaikan, menghargai pendapat para anggota serta memberikan pertimbangan terhadap saran dan ide yang diterima”. Mulyasa (2009) menyatakan bahwa kepala sekolah yang demokratis menyadari bahwa dirinya marupakan bagian dari kelompok, memiliki sifat terbuka, dan memberikan kesempatan kapada para tenaga kependidikan untuk ikut berperan aktif dalam membuat perencanaan, keputusan serta menilai kinerjanya. Kepala sekolah yang demokratis memerankan diri sebagai pembimbing, pemberi petunjuk, serta bantuan kepada tenaga kependidikan. Oleh karena itu, dalam rapat sekolah kepala sekolah melibatkan diri secara langsung dan membuka interaksi dengan tenaga kependidikan, serta mengikuti berbagai kegiatan rapat sekolah.

Hasil wawancara di atas, diperkuat dengan data yang peneliti dapatkan melalui pengamatan di mana dalam memimpin rapat atau pertemuan, kepala sekolah selalu menjunjung nilai-nilai mufakat dan musyawarah. Kepala sekolah selalu memusyawarahkan berbagai persolan sekolah, demokratis dan menghargai pendapat para guru dan pegawai. Kepala sekolah selalu meminta saran, masukan dan ide dari para peserta rapat. Kepala sekolah juga memberikan berbagai macam bentuk alternatif pemecahan masalah yang dibicarakan dalam rapat, dan menyerahkan yang terbaik pada forum rapat.

\section{Pengambilan Keputusan oleh Kepala Sekolah}

Kepala sekolah adalah pengambil keputusan. Purwanto (2010) menyatakan bahwa pengambilan keputusan merupakan kegiatan yang selalu kita jumpai dalam setiap kegiatan kepemimpinan. Bahkan dapat juga dikatakan, bagaimana cara pengambilan putusan yang dilakukan oleh seorang pemimpin menunjukkan bagaimana gaya kepemimpinannya. Dengan demikian, pengambilan putusan merupakan fungsi kepemimpinan yang turut menentukan proses dan tingkat keberhasilan kepemimpinan 
itu sendiri. Dalam menjalankan fungsi dan tugasnya, keputusan kepala sekolah merupakan hal yang sangat memberikan pengaruh yang besar tehadap lembaga pendidikan yang dipimpinnya.

Dalam hal ini, peneliti mempereroleh data melalui wawancara dengan beberapa orang guru (30 November sampai 3 Desember 2015) di mana dinyatakan bahwa "kepala sekolah melakukan pertimbangan yang cukup matang, meminta saran kepada para guru, mengambil keputusan dengan jalan musyawarah, tidak memaksakan kehendak sendiri, bijaksana, terbuka, keputusan itu diambil secara bersamasama dan sikap kekeluargaan tanpa harus memaksa kehendak pribadi”. Namun di sisi lain, adakalanya kepala sekolah mengambil keputusan langsung dengan pertimbangan bila mengambil pendapat yang lain akan menimbulkan permasalahan yang baru.

Menurut Pramono, Hamid dan Mukzan (2013) dan Nawawi (2003) beberapa fungsi pemimpin adalah sebagai pengambil keputusan di mana suatu organisasi akan berjalan dinamis jika pemimpin mempunyai kemampuan untuk mengambil keputusan yang nantinya akan dilaksanakan bawahannya. Fungsi ini sangat penting peranannya karena tanpa mampu dan berani mengambil keputusan pemimpin tidak akan dapat menggerakkan anggotanya.
Di samping itu, hasil pengamatan peneliti, di mana dalam mengambil keputusan, kepala sekolah selalu bermusyawarah terlebih dahulu dengan para guru dan pegawai. Kepala sekolah memberikan kesempatan pada forum rapat sebelum mengambil keputusan agar menyampaikan ide dan pendapat mereka. Bahkan tak jarang dalam pengambilan keputusan kepala sekolah menyerahkannya pada forum rapat. Dalam hal ini, kepala sekolah tidak bersifat otoriter dan memaksakan pendapatnya pada forum. Berbagai pertimbangan dilakukan oleh kepala sekolah sebelum memutuskan suatu perkara dan permasalahan.

\section{Sikap Kepala Sekolah kepada para Guru dan Pegawai}

Berdasarkan data yang diperoleh melalui wawancara (30 November - 3 Desember 2015) dimana sikap kepala sekolah terhdapa para bawahannya, baik guru dan pegawai yakni humoris, pengertian, kekeluargaan, terbuka, disiplin, ramah, penuh pertimbangan, tidak membedakan status para bawahanya, menyamaratakan tugas dan kewajiban, tegas, baik, dan bersahabat, kekeluargaan, dalam menyelesaikan permasalahan tergantung situasi. Hal sama juga penulis dapatkan data dari pengamatan bahwa sikap kepala sekolah terhadap para bawahannya yakni tidak membeda - bedakan para bawahannya, baik 
yang berstatus sebagai PNS atau pun non PNS. Kepala sekolah bersikap terbuka, kekeluargaan, dan tak jarang untuk bersikap humoris.

Dalam upaya menyatukan para bawahannya kepala sekolah melakukan tindakan berupa menyediakan pakaian seragam, menerima insentif yang sama, memberikan tugas dan tanggung jawab yang sama kepada setiap guru tanpa membedakan status, mengikutsertakan dalam kegiatan apapun, memberikan tanggung jawab terhadap tugas yang diembankan, serta membaur dalam mengambil suatu keputusan. Kemudian dari wawancara dengan beberapa orang guru juga diperoleh data bahwa "dalam membangun kerja sama tim kepala sekolah melibatkan semua guru dalam kegiatan-kegiatan sekolah tanpa membedakan status kepegawaian. Sikap kepala sekolah selalu terbuka, disiplin, menerima kritik dan saran, toleransi, kebersamaan, kekeluaragaan, adil dalam memberikan tugas dan tanggung jawab, demokrasi, dan tidak berlaku otoriter".

Di sebuah organisasi dan lembaga, tidak jarang juga terjadi pelanggaran terhadap aturan yang berlaku. Dalam hal ini, dari data yang kami peroleh melalui wawancara di mana apabila terjadi pelanggaran, tindakan yang diambil oleh kepala sekolah yakni menyampaikan teguran secara lisan dalam suasana kekeluargaan, teguran berupa sanksi tertulis, melakukan pengurangan nilai dalam kegiatan pada PKG, bimbingan dan nasehat, memberikan pengarahan, peringatan, memanggil guru yang bersangkutan, memberikan sanksi secara kekeluargaan dan memberikan solusi yang terbaik, dan menanyakan permasalahan yang terjadi dan kemudian memberikan masukan. Di samping itu, jika terjadi pertikaian atau kesalah pahaman antara para guru atau pegawai, kepala sekolah bersikap tidak memihak kepada salah satu pihak, tegas, demokratis, kekeluargaan, memberikan nasehat, memberikan solusi dan pertimbangan, memberikan keputusan secara bijaksana, mencarikan jalan keluarnya dan memberikan bimbingan secara kekeluargaan, membicarakan bersamasama, sabar, serta mendengarkan dulu permasalahanya lalu diambil keputusan.

Secara keseluruhan, mengenai gaya kepemimpinan kepala sekolah, menurut Santoso \& Setiawan (2013) dan Fahmi (2012) bahwa pemimpin yang ideal dengan ciri-ciri yaitu 1) human relationship; 2) comunication skill; 3) teaching skill; 4) social skill; dan 5) technical competent. Hasil temuan dalam penelitian ini senada dengan penelitian yang dilakukan oleh Uzlah (2011) bahwa berdasarkan hasil statistic diperoleh koofisien korelasi (r) 0,880 dengan signifikansi ( $\mathrm{p}$ ),000 di mana $\mathrm{p}<0,005$ 
dengan demikian hipotesinya menyatakann ada hubungan yang signifikan antara persepsi gaya kepemimpinan atasan dengan kepuasan kerja. Uzlah (2011) mengungkapkan persepsi gaya kepemimpinan atasan merupakan cara bagaimana pegawai melihat, memahami dan memberikan penilaian terhadap kualitas dan karakteristik atasan dalam suatu hubungan interpersonal. Pegawai yang melihat, memahami dan menilai atasannya sebagai atasan yang mampu memberikan inspirasi, optimis dalam mengatasi masalah, memberikan hadiah apabila mereka bekerja dengan optimal, memberikan pujian atas hasil kerja yang membanggakan, mendukung ideide mereka, dapat membuat pegawai merasa pekerjaan di Puskesmas sebagai kegiatan yang menyenangkan, pekerjaan yang diberikan pada mereka membuat mereka tertantang, membuat mereka bekerja dengan semangat karena akan dipromosikan apabila memiliki prestasi kerja yang membanggakan, mereka merasa penghasilan di Puskesmas sebanding dengan apa yang mereka kerjakan, mereka merasa teman kerja dapat meningkatkan pekerjaan mereka serta mereka merasa ruang kerjanya terasa nyaman.

Artinya, penelitian di atas menggambarkan keadaan dan iklim yang kondusif serta kerja tim yang baik berwal dari persepsi yang baik dari para pegawai terhadap atasannya. Tentunya, persepsi yang baik dan positif tersebut tidak datang dengan sendirinya, melainkan datang dari sikap pimpinan yang baik pula. Semua ini tercipta sebagai bentuk kerja sama yang baik, hubungan yang baik dan suasan kerja yang kondusif.

Di samping itu, penelitian yang hampir senada dengan penelitian ini dilakukan oleh Pramono, Hamid dan Mukzan (2013), mengungkapkan bahwa bapak Herik Satrio selaku pimpinan selalu berkomunikasi dengan karyawan karena hal tersebut sangat penting apalagi menyangkut masalah pelayanan. Komunikasi selalu dilakukan melalui pertemuan-pertemuan rutin antar karyawan, baik di saat jam kerja maupun di luar jam kerja. Pimpinan juga selalu memberikan kesempatan bicara dan mengemukakan pendapapat pada saat rapat rutin ataupun pada saat kondisi informal.

\section{KESIMPULAN}

Kepala sekolah telah mampu menjalin hubungan komunikasi dan interaksi yang baik dengan para guru dan bawahannya, serta para siswa. Kepala sekolah dalam meningkatkan kinerja guru telah memberikan dukungan atau motivasi pada para bawahannya berupa reward dan pujian yang disampaikannya. Kepala sekolah telah menjalankan tugas dan fungsinya sebagai seorang pemimpin yakni memberikan bimbingan dan arahan pada para bawahnnya, 
baik berupa bimbingan akedemik, kerier dan bimbingan sosial. Dalam melaksanakan pertemuan dengan para bawahnnya, kepala sekolah telah menanamkan nilai-nilai demokrasi. Dalam upaya pengambilan keputusan, kepala sekolah selalu melakukan musyawarah terlebih dahulu dan mengambil keputusan berdasarkan pertimbangan ide dan pendapat para bawahannya. Kepala sekolah telah berupaya untuk menciptakan kerja sama yang baik dan iklim organisasi yang kondusif di SD Negeri 11 Kapeh Panji.

\section{KEPUSTAKAAN ACUAN}

Daryanto. (2008). Administrasi Pendidikan. Jakarta: Rineka Cipta.

Djama'an, Satori \& Aan, Komariah. (2011). Metodologi Penelitian Kualitatif. Bandung: Alfabeta.

Holloway, Joseph B. (2012) "Leadership Behavior and Organizational Climate: An Empirical Study in a Non-profit Organization Emerging Leadership". Journeys, Vol. 52012.

Kothari, C.R. (2004). Reseacrh Methodology Methods and Techniques. New Delhi: New Age. International Publisher.

Mulyasa, E. (2009). Menjadi Kepala Sekolah Profesional. Bandung: Rosda Karya.
(2009). Manajemen Berbasis Sekolah. Bandung: Rosda Karya.

Munaroh. (2011). "Pengaruh Gaya Kepemimpinan Transformasional dan Transaksional Terhadap Kinerja Guru”. Jurnal Ekonomi Bisnis No 2 Tahun 2011.

Pramono, Nanok Hadi. Hamid, Moehammad Djamhur. Mukzan, Djudi. (2013). "Peranan Pemimpin dalam Memotivasi Karyawan”. Jurnal Jurnal Administrasi Bisnis (JAB) Vol. 6 No. 2 Desember 2013.

Permadi, Dadi dan Arifin, Daeng. (2011). Kepemimpinan Transformasional Kepala Sekolah dan Komite Sekolah. Bandung: Sarana Panca Karya Nusa.

Purwanto, Ngalim. (2010). Administrasi dan Supervisi Pendidikan. Bandung: Rosda Karya.

Rohiat. (2010). Manajemen Sekolah. Bandung: Refika Aditama.

Santoso, Pohan Susanto dan Setiawan, Roy. (2013). "Studi Deskriptif Gaya Kepemimpinan dan Kinerja Karyawan di PT. Galang Buana Sentosa”. Jurnal Agora Vol. 1 No. 3 Tahun 2013.

Sarwono, Jonathan. (2006). Metode

Penelitian Kuantitatif dan Kualitatif.

Yogyakarta: Graha Ilmu 
Supriadi, Oding. (2009). "Pengaruh Gaya Uzlah, Siti Maria. (2011). "Hubungan Kepemimpinan dan Kualitas Layanan Antara Persepsi Gaya Kepemimpinan Terhadap Mutu Pendidikan di Kabupaten Atasan Dengah Kepuasan Kerja Pegawai Pandagelang Provinsi Banten”. Jurnal Puskesmas Mekar Baru”. Jurnal Psikologi Tabularasa Vol 6 No. 2 Tahun 2009. Volume 9 Nomor 2, Tahun 2011.

Susilo, Wilhelmus Hary. (2010). Penelitian Kualitatif Aplikasi Pada Penelitian Ilmu Kesehatan. Susilo dan Ivy. 